\title{
The Strategic Value of Price Communication
}

\author{
Andreas Krämer \\ University of Applied Sciences Europe \\ Faculty of Economy, Iserlohn, Germany
}

\begin{abstract}
Price communication is increasingly relevant in practice but is not sufficiently appreciated in research. Changed framework conditions, e.g. due to new price models in the context of digitalization or changed consumer behaviour, mean on the one hand that price communication has become more complex and on the other hand that new challenges on price communication have arisen. Overall, price communication should not be viewed as an isolated but as a pivotal part of overall pricing strategy.
\end{abstract}

Keywords: price communication, VUCA, digitalization, pricing process, price strategy.

\section{INTRODUCTION}

If the components of price management are placed in relation to their attention in theory and practice, it can be seen that the topic of price communication has led a shadowy existence in recent years. After all, prices not only have to be calculated and checked for their effects on sales and profits as well as for consistency, they must also be communicated. In times of strongly changed and very dynamic environmental conditions, price communication has to face new challenges and requires new approaches. In this context Meffert 1 explains: "We basically have a completely different world in which communication is different and in which smart, fast and intelligent solutions can be found!" The changed framework conditions are multi-layered and complex. Among other things, they include changes in intake, provision 2 and the increased availability of price information as well as a generally stronger dynamization of prices 3. From a communication point of view, digitalization and real-time communication are leading to structural changes in the media and communication markets. A large number of new technology-driven communication possibilities have emerged, which, among other things, make it possible to implement a personalized and individual pricing approach quickly and flexibly. At the same time, the term VUCA (short for Volatility, Uncertainty, Complexity, Ambiguity) has found its way into the vocabulary of management and is often equated with "unpredictable change" 4.

Under these circumstances, the first section of this paper provides a classification of price communication. In addition, areas of application are discussed in order to illuminate how the changed framework conditions affect the relevance of price as part of corporate communication, which drivers play a role here and which challenges must be overcome in the future. 


\section{PRICE COMMUNICATION: CLASSIFICATION AND AREAS OF APPLICATION}

\section{Classification: price and communication in theory and practice}

The term price communication - a connection between price and communication, which can be found in the two marketing instruments price policy and communication policy - has so far been seen less as a cohesive force in theory and practice, but is usually viewed separately 5 .

\section{Price communication within the framework of communication policy}

Communication policy is less an isolated function in the marketing mix, but rather to be coordinated with the other marketing instruments. When explaining the facets of corporate communication Cornelissen 6 is unilaterally limited to the function of price as a part of the marketing mix. In contrast Van Riel and Fombrun 7 concentrate on the communication of companies to stakeholders and consider the issue of pricing related to positioning aspects. Overall, the topic of product prices does not play a significant role. Bruhn 8 explicitly points out the relationship between pricing and communication policy, e.g. if the effect of a certain price level, as in the case of a company's low-price strategy, can only be achieved due to intensive communication. But even here, there is only a narrow view on price as an element of corporate communication.

A more detailed examination of the scientific literature on the subject of communication policy reveals that the topic of price communication is concentrated on certain core topics, namely (1) possible advertising messages such as highlighting the unique selling proposition, price worthiness or price advantage 9 , (2) sales promotion measures such as promotional campaigns and coupons 10 or (3) a form/measure of personal communication such as in price negotiations or annual talks between manufacturers and retailers 11 12. In total, the topic of price and communication in the relevant standard text books on communication management or communication policy is reduced to approx. $100-120$ words of over 650 pages.

\section{Price communication in the context of pricing policy}

Reviewing the scientific literature from the perspective of price management comes to a similar conclusion. In their text books Simon and Fassnacht 13 dedicate 14 of more than 600 pages (2\% of all pages) to the topic of price communication. In Diller's book on price management 14 the facet of communication policy considerations is addressed in one chapter on price implementation (20 out of 522 pages), particularly with regard to price advertising. Olbrich and Battenfeld 15 deal with the topic even less. When discussing price-psychological approaches authors often focus on the effect of price displays and the influence of communication on price perception and assessment 14 13. Schindler (2012) emphasizes the issue of inadequate communication of prices and highlights in particular the legal framework 16. Also, Baker, Marn and Zawada 17 only deal with selected aspects of price communication (new products, price changes, price wars and innovations). In contrast, Smith completely lacks the corresponding connections 18.

To summarize: the search for a systematic approach to and discussion of the subject of price communication is less successful, even with special consideration of sector-specific requirements, although these are becoming increasingly relevant in practice. At the same time statements such as those made by the consulting company Vocatus 19, that facets such as price structure, price dynamics and price communication are much more important than the pure price level for purchase decisions, are increasingly being listened to by the marketing managers of companies and 
Kramer, A. (2020) The Strategic Value of Price Communication. Archives of Business Research, 8(5). 96-111.

are leading them to rethink. Today, the increasing determining role that Behavioural Pricing plays in price management suggests the image of a human decision maker who can be strongly influenced. This is also confirmed by the controversial discussion about choice architecture and nudging 2021.

\section{Integration of price communication as a key function of the pricing process}

Typically, price communication starts in the phase when the determination of price levels or the determination of price structures has been set internally and is therefore irrevocably fixed for the time being, i.e. until the next adjustment, and must now be mediated. It is an integral part of the price management planning process, in which the various tasks in price management are coordinated.

The pricing process is also referred to as one of the most important value creation processes of companies due to the high importance of the price as a profit driver 12 . Simon and Fassnacht 13 define the price management process as a system of rules and procedures for setting and enforcing prices, whereby the process consists of the four phases strategy/framework, analysis, decision and implementation. In Fig. 1 the course of a pricing process is described in a more detailed model (9$\mathrm{C}$ model). Here, 9 key elements within the pricing process are presented, of which step number 8 concerns price communication in the context of price implementation.

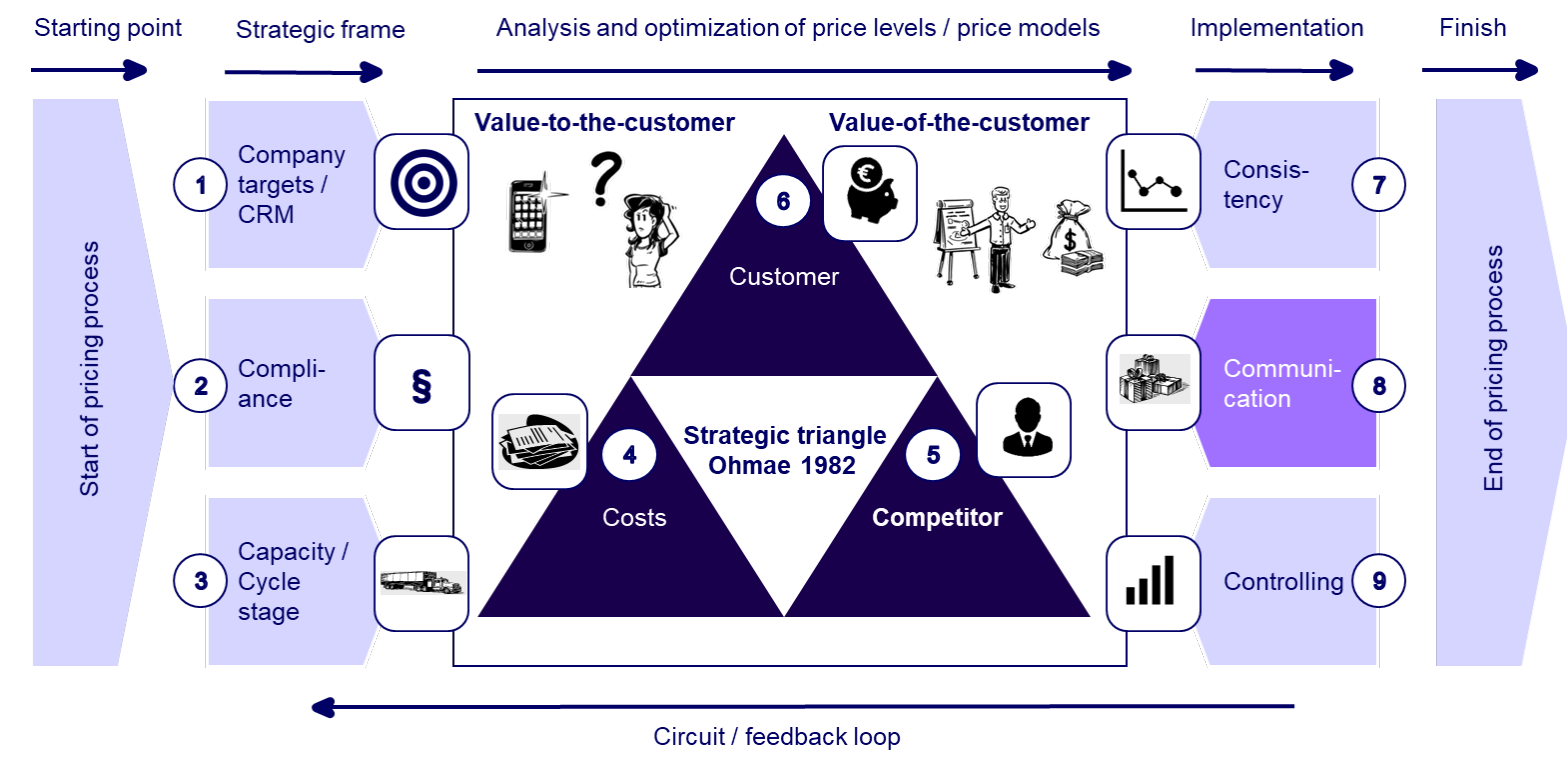

Fig. 1: The 9-C model and the pricing process

The cornerstones of price optimization are (1) the customers' willingness to pay, (2) cost structure of the own company and (3) the positioning of the competition 22. Digital business models sometimes generate high customer benefits (value-to-the-customer). As Reisman and Bertini 23 complain, however, many companies do not manage to capitalize on this sufficiently. Within the framework of so-called value-based pricing, an attempt is made to exploit the customers' willingness (perceived value) to pay as far as possible 2425 26. In this case, the value-of-thecustomer should increase while the consumer surplus decreases (value-to-the-customer) 27. Value communication is crucial both, externally and internally: prices have to be communicated to customers in order to influence price perception and assessment in terms of overall positioning. 
However, it is just as essential that the current price information, targeted price ranges as well as responsibilities are transparent and comprehensible for employees and that there is a commitment to implement prices as planned.

\section{Trigger of price communication}

As described above, price communication is a crucial part of the implementation phase in the pricing process. In order to generate a deeper understanding of price communication, the next step is to examine its triggers: product innovations and differentiations, price adjustments and changes in price structures or complete price systems.

\section{New products}

Having in mind the high flop rates of new products in the range of 50 to 75 per cent $(28 ; 29)$ or values of over 90 per cent for start-ups 30, efficient communication with the end customer is highly relevant. An essential characteristic of innovations is that customers are uncertain about the functional and symbolic benefits in the social environment as well as the costs 31 . Cost-related uncertainties refer to financial uncertainty, learning certainty with regard to innovative functions and affective uncertainty, i.e. replacing the familiar with the innovation $(32 ; 31)$. During the market introduction phase, it is necessary to build up the targeted price image through price communication. According to Gröppel 33, price image is to be understood as the subjective generalization of price judgments about a particular supplier.

\section{Product modifications and product differentiation}

Product modifications involve comprehensive changes to one or more product properties of a product already launched on the market [34]. Usually, the aim is to extend the life of a product.

In the case of product differentiation, new product variants are introduced to the market for products that have already been launched, which are intended to specifically address the needs of different target groups. The number of products in the product range is increased compared to product modification 33. Product differentiation is often accompanied by performance-related price differentiation. For example, when Germanwings launched its low-cost product in 2002, it initially offered only one class or comfort range, which was later expanded to two and then three performance levels. With a modularized service, it is important to achieve active control of demand through targeted communication 35. This becomes especially important in case of ancillary pricing, which is also typical in the airline industry 36 and often critically evaluated when discussed in relation to customer fairness perceptions 37.

\section{Price changes/adjustments}

Regardless of product modifications or differentiations, companies find themselves in a situation where they have to adjust the prices of products throughout their life cycle. This may be the case ([34]; 38), e.g. if (1) internal costs have changed due to experience curve effects, but also investments in e.g. new technological developments, (2) external costs such as raw material costs have changed, (3) new competing products come onto the market, (4) competitors change their prices, (5) the price is used as an essential instrument to attack competitors, (6) a price reaction to competitive attacks takes place, (7) demand increases or decreases or (8) sales are to be temporarily promoted (special offer prices). Here, too, it is important to explain the adjustment of prices to customers in a transparent and comprehensible manner. Ferguson and Ellen 39 point out: 
Kramer, A. (2020) The Strategic Value of Price Communication. Archives of Business Research, 8(5). 96-111.

"Perceived price fairness is affected by who discloses the price increase, the amount of the price increase and the extent to which reasons are revealed and aligned with the firm's costs."

\section{New pricing models/rates}

More significant changes than simply adjusting the level of prices or conditions concern the conversion of pricing models, the introduction of new tariff structures or the complete restructuring of pricing systems. In this case, there are particularly great opportunities, but also risks. The challenge lies in the fact that stakeholders involved (customers, sales partners, sales staff, etc.) not only understand and internalize several changes simultaneously, but also have to deal with increased complexity. This requires a particularly cautious approach externally (communication advantages towards the market) and internally (training of the employees, establish guidelines for the sales force etc.).

\section{DETERMINING FACTORS FOR THE INCREASED RELEVANCE OF PRICE COMMUNICATION}

The above-mentioned primary areas of application are strongly affected by changes in technical, social and economic developments. Hence, three drivers are examined in more detail below: Firstly, a stronger implementation of price differentiation, secondly, changed strategic pricing considerations of the companies and thirdly, the changed framework conditions for communication (see Figure 2). Here, a total of 10 individual effects are assigned to the three main drivers.

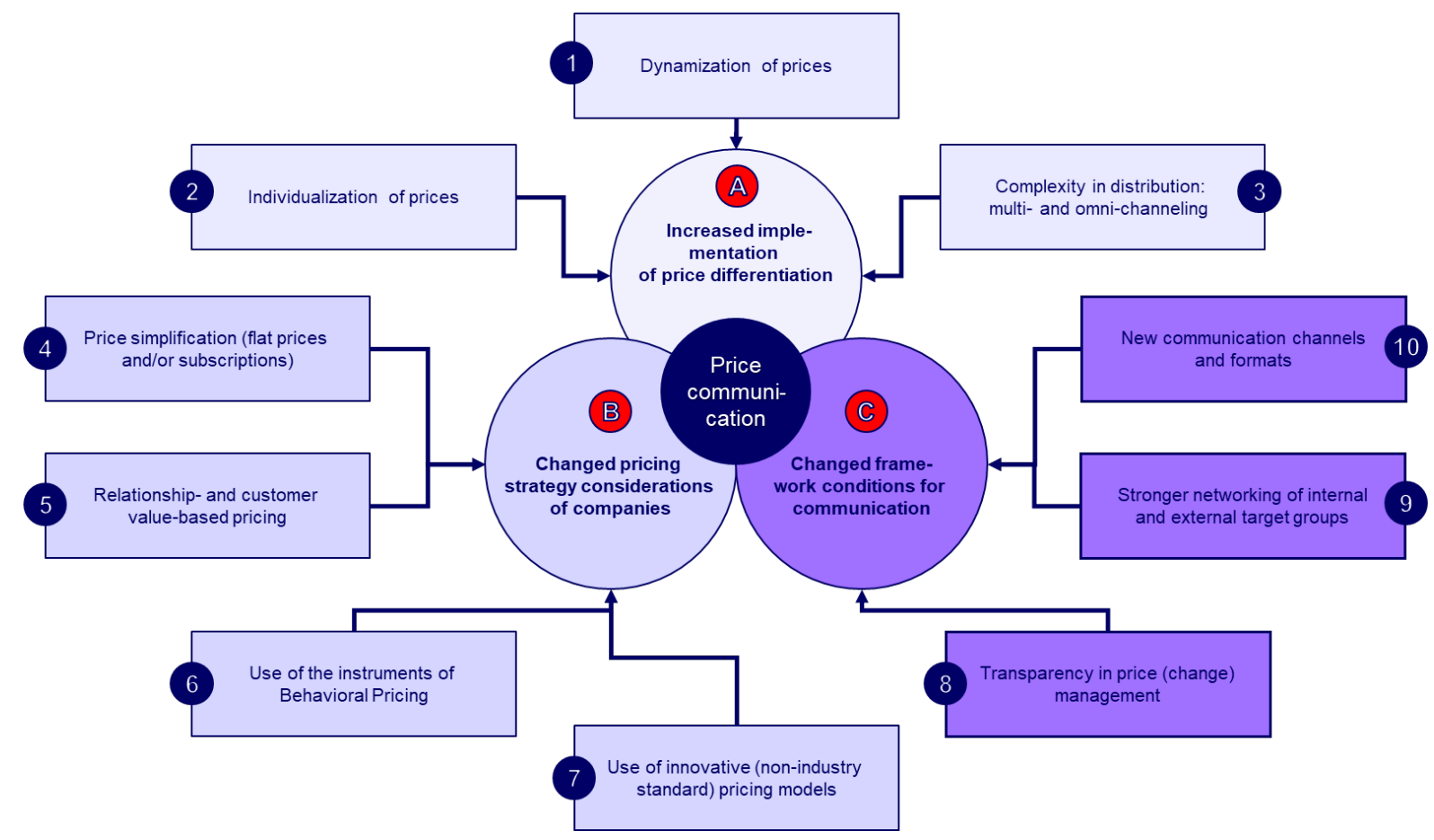

Fig. 2: Changing framework conditions affecting the relevance of price communication

\section{Increased implementation of price differentiation}

In the context of an increasing digitalization of the economy, it is necessary to separate the terms business model, revenue model and price model more strongly from each other and to discuss their dependencies $(2 ; 12)$. If a modified business model enables several sources of revenue, building differentiated pricing models is required. In addition, the dynamization and individualization of 
prices as well as increased price differentiation via the sales channels used must also be considered.

\section{Dynamization of prices}

With dynamic pricing, the sales price is adjusted to the current market. The product price thus becomes a variable that can be changed quickly over time. If demand increases, the price is adjusted and increased accordingly. If demand stagnates, the suppliers give a new impulse to purchase by reducing prices 40 . This dynamization of prices also results in a dynamic communication of price levels and changes. Furthermore, the link between dynamic pricing and perceived price fairness 41 or between flexible product prices and brand management have to be examined in this context 42. New individualized, real-time price communication measures based on customer-specific profiles and requirements are necessary. Overall, this increases the requirements for efficient price communication. Thus, the strong variation of prices also has its own communication effect. For example, Viglia et al. 43 refer to the effect of dynamic prices on the reference prices of consumers and argue that "people tend to overstate lower prices". When the long-distance bus service BlaBlaBus was launched in Germany (June 2019), the company communicated price points of 0.99 EUR per route with the promise that they would apply for the entire introduction phase (until September 2019). While dynamic prices have long been standard in industries such as airlines, hotels or car rentals, dynamic pricing has recently been gaining ground in other areas such as sporting events 44, ski passes 45 or car parks 46 . Even food retail has now also discovered the opportunity of dynamic prices. In late 2019 is became public that the German discounter Lidl is testing electronic price tags in order to be able to adapt price levels to different market situations 47.

\section{Individualization of prices}

Conditions for individualized prices (and discounts) are given if customers' willingness to pay is heterogenous, customers can be contacted directly (e.g. via a customer account or an app) and sufficient data is available. For an increasing number of companies - beyond the classical eCommerce - these possibilities are improving. For example, Deutsche Bahn offers customers who participate in the customer loyalty programme BahnBonus travel vouchers depending on the value of the booking (e.g. a discount of EUR 15 on the purchase of a ticket worth at least EUR 59) by email (the redemption period is limited). In the further development there will be possibilities to personalize the prices dynamically.

Basically, price personalization is not a new phenomenon but gaining in practical importance. The Payback bonus program has been collecting customer data since 2002 and offers individualized coupons via micromarketing 48. Allianz Travel Insurance also recently announced that it would be adjusting its insurance premiums more closely to the individual risk. Destinations, age group and the exact travel price are included in the individual calculation 49.

\section{Complexity in distribution: multi- and omni-channeling}

The expansion of distribution channels is accompanied by the question of whether prices in offline distribution channels should be identical to those in online/mobile distribution. Factors such as varying customers' willingness to pay and competitive situations are driving forces. However, price dispersion can also lead to customer confusion if price differentiation is not clearly communicated. This partly explains the fact that some retailers are focusing on price 
Kramer, A. (2020) The Strategic Value of Price Communication. Archives of Business Research, 8(5). 96-111.

differentiation, while others are foregoing it 50. In a large-scale comparison of online and offline prices in large, multi-channel companies (56 of the largest retailers in 10 countries), Cavallo (2017) comes to the conclusion that in $72 \%$ of cases online and offline price levels are identical 51.

Due to a different price perception according to distribution channels, especially the price fairness assessment as well as the shopping experience in stationary retail can be endangered from the viewpoint of the consumer. The complexity for price communication increases even more if, in addition to multi-channel sales, different price levels and models have to be communicated, as is the case in the sanitary industry described by Keldenich 52 .

\section{Changed pricing strategy considerations of companies Price simplification (flat prices and/or subscriptions)}

Strategies of price simplification are considered a new counter-trend: The more differences in customer needs are prevailing, the more effective it is to offer different price models in direct competition. At the time subscription offers (e.g. in combination with flat pricing) can be regarded as the counter-pole to differentiated pricing 3 . Here, customers pay a uniform price and decide what and how much they consume. This promises a high value-to-the-customer, while the valueof-the-customer aspect (customer value from the company's point of view) cannot be assessed easily (costs of service provision are not stable). Finally, the profitability of the subscription service depends not only on the subscription price, but also on the actual use of the subscription service(s) and the costs of service provision.

The music streaming service Spotify is a good example for a situation in digital business models where incremental costs are not zero 12. The more user stream music the higher the costs for Spotify. Today, the coexistence of different pricing models is often the rule rather than the exception. For example, in Germany eTariffs in local public transport are currently being introduced or tested almost nationwide, while at the same time (for target groups such as senior citizens or trainees) flat prices in the form of monthly or annual tickets are being introduced on the market 53. In Germany, a flat-price of 365 EUR for unlimited year-round use will be introduced in some areas ("public transport for one Euro a day", according to the so-called "Vienna model"). In ecommerce Amazon relies on the strength of the subscription offer (Prime) on the one hand, and on dynamic pricing for product sales via its own platform on the other. This requires a clear, transparent storyline to convey the benefits of the different pricing models and avoid to damage customer loyalty.

\section{Relationship- and customer value-based pricing}

For customers in the telecommunications sector it is not uncommon, for example, to receive the message that certain promotional offers are only available to new customers, while long-standing customers of the company are excluded. What may seem conclusive from the perspective of stringent value-based pricing (prices are formed according to the willingness of individual customer segments to pay) cannot be clearly justified from the perspective of customer relationship management (CRM) 22. After all, the revenue and profit generated from an existing customer relationship can be much greater than that of a new customer 27.

In order to be able to recognise and accept this correlation and ultimately include it in pricing, it is necessary to quantify the relationship between business success and the duration of the customer 
relationship and to calculate or classify the customer value 22. Following this logic, Lewis 54 suggests besides discounting for new customers also offering a reduced discount level depending on the duration of the business relationship. This is justified by the positive effect of price discounts for existing customers on their lifetime value. An example of this is the widespread use of discount cards in long-distance rail transport. Thus, relationship pricing focuses on the medium to longterm profitability of the customer relationship $(55 ; 56)$, with a corresponding influence on strategic positioning and price communication.

\section{Use of the instruments of Behavioural Pricing}

Although there is a hype surrounding Behavioural Pricing, it has to be stated that not all the instruments discussed in this context have a major impact $(57 ; 58)$. Nevertheless, it is possible to influence price perception. In this context Vöster 59 describes: "If (apparently) contradictory, stated irrational consumer behaviour follows certain rules and patterns, this conversely means that many phenomena are foreseeable and can therefore be controlled by companies in a targeted manner." However, most effects are likely to be more context-dependent and the irrationality of the decisions may also be questioned 60. One problem here is the almost unmanageable number of effects that are highlighted in research. In his overview article Larson presented no less than 50 different approaches 61.

In any case communication effects should be subjected to a pre-test 62 . A promising approach is to influence customers' reference price, which makes one's own offer appear very cheap. For example, the insurance start-up Friday advertises car insurance starting at a price of 1 cent per kilometre 63. This is a combination of the pay-per-use approach ("I only pay if I use my car") and the "pennies-a-day" approach (instead of the total costs per year, the price per $\mathrm{km}$ is given priority).

\section{Use of innovative (non-industry standard) pricing models}

In the pricing community there are intensive discussions on the topic of innovations in pricing. Hinterhuber and Liozu 64, for example, question whether innovative pricing models can also become a competitive advantage and list more than 20 possibilities. One option is a modified price framing, in which the focus is redirected from product price to user price (e.g. Mobility as a Service). In recent years, the range of integrated mobility services has increased steadily. The predominant pricing models are pay-per-use or monthly subscription fees 65 . While other car makers are pushing car sharing as a strategic option, Volvo has been taking a different approach with its "Care by Volvo" offer 66. Similar to the concept of the start-up Cluno or by the car rental company Sixt, car usage is offered based on a subscription. Customers pay a fixed fee, which covers all costs related to the car except fuel.

New pricing approaches are particularly demanding in terms of communication, and have been the subject of much discussion in recent years 67: These include participatory pricing approaches such as "pay-what-you-want", "name-your-own-price" (NYOP, such as Priceline.com) or online auctions. In contrast to the methods of classic price management, the buyer has a greater influence on the pricing process. 
Kramer, A. (2020) The Strategic Value of Price Communication. Archives of Business Research, 8(5). 96-111.

\section{Changed framework conditions for communication Transparency in price (change) management}

Within the framework of more networked communication, there are limits to "hidden" price increases. Companies that have managed in the past to push through price changes of 20 percent and more per year, while adjusted prices were either not at all communicated or were communicated in connection with a changed scope of products and services (e.g. package size, design etc.), are now taking greater risks. Once individual providers are discussed in a broader public ("cheat package of the month", blogs in the social media, etc.) the challenges on communication become very high. For this reason, companies should consider whether it might not make sense to actively and transparently announce price adjustments, leading to positive effects and impacts on customer relations. One example is the German juice manufacturer "beckers bester" which argued to be forced to increase product prices as a result of a poor apple harvest 68.

\section{Stronger networking of internal and external target groups}

Price communication becomes particularly relevant when new products are introduced to the market, when existing products are changed in price and when the pricing model or even entire pricing systems are subject to change. During such a process the different interfaces between the company and the different stakeholders play an increasing role. In addition, digitalization makes the management of the wide range of customer contacts more demanding 69. At different points of customer contact, price can become a point of discussion.

This is particularly critical for employees with customer contact who were originally not involved in the pricing process (e.g. in B2C markets: employees in the customer care centre; in B2B markets: employees from sales; see Grund 70). Due to stronger networking, real-time communication and at the same time increased price transparency as well as stronger dynamics, price-related topics (level, structure, fairness etc.) are more frequently a point of discussion. Here, employees become the pivotal communication interface, as Lauszus and Bastgen point out 71. At the same time the sales team can make a valuable contribution, especially during the introduction phase of new tariff and condition systems 72. Among others, employee's identification and commitment are key success factors.

\section{New communication channels and formats}

The use of new digital communication channels on the one hand expands the number of communication channels to customers, but on the other hand influences the form and style of communication. In this new environment, price communication must adapt to the changing communication behaviour of the stakeholders. Price information can be communicated in real time via videos, e.g. press conferences or new product launches can be transmitted live on the Internet. Moving images are also suitable, for example, for explainer videos to justify price increases, such as those used by the family-owned company beckers bester, mentioned above 68 or to train/"educate" employees with regard to necessary changes in the price structure and provide them with guidelines for interaction with the customer 73.

Furthermore, the digital media enable each individual employee to communicate with their private or professional networks as brand ambassadors and thus have a viral multiplier effect on all external stakeholders, also with regard to communicating prices and benefit arguments. Today, it is no longer unusual for a CEO to announce sales figures or prices via Twitter. In August 2019, 
Tesla's largest shareholder (the Scottish investment firm Baillie Gifford) demanded the replacement of CEO Elon Musk not because of poor business figures, but because of erratic, inconsistent and uncoordinated communications (primarily via Twitter; as reported by Fallon 2019 74).

\section{TARGET GROUPS AND DEPENDENCIES OF PRICE COMMUNICATION}

The importance of communicating prices to customers as well as the necessity of internal communication has already been pointed out in the explanation of the implementation phase of the pricing process. However, a superficial distinction between internal and external orientation is not enough. Rather, the internal and external target groups must be further differentiated (cf. Figure 3), once they are addressed via operative marketing measures.

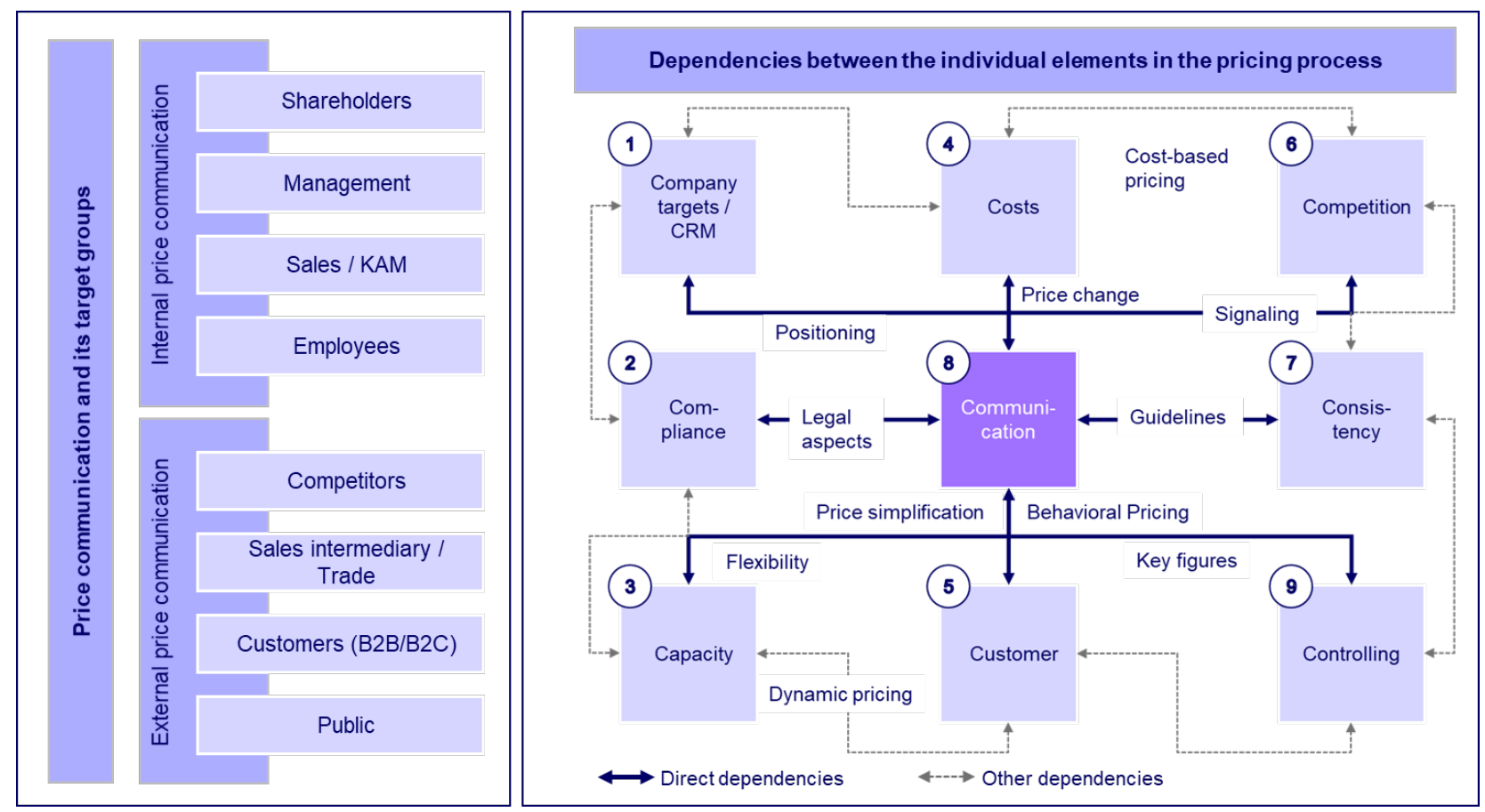

Fig. 3: Target groups and dependencies of price communication

\section{Internal price communication}

As highlighted by Lauszus and Bastgen research and standard text books on price management acknowledge the importance of internal price communication as part of implementation 71, but only marginally refer to the "how" 75 . Internal target groups include shareholders, management, sales/key account management (KAM) and employees in other areas (production, accounting, etc.). The shareholders should be informed comprehensively, especially because the setting and changing of prices depending on the objective have essential rapid effects on sales, market share and profits of a company 13. Shareholders should be informed about the desired effects of the pricing measures in order to reduce uncertainties and show a clear perspective. In special situations, e.g. in medium-sized companies, it is sometimes customary that the families or shareholder representatives involved reserve the right to intervene more strongly in the operative business. Price changes have the potential to become a "political issue". This is particularly the case in times of crisis, when the perception of companies is particularly sensitive and price increases are viewed with particular suspicion. 


\section{External price communication}

External price communication is directed at competitors, sales intermediaries/traders, B2B customer companies and/or end customers in the B2C market as well as the general public (Fig. 3).

When communicating in the direction of competitors (signalling), the question arises as to how their behaviour can be influenced in terms of their own objectives 76. In such cases, an attempt is made either to prevent competitors from reacting with regard to price or to motivate them to behave in the same direction 13, in order not to provoke price competition or, in extreme cases, a price war 77 or to end price wars that have already begun 78. Under anti-trust law, communicative coordination of pricing policy with competitors is prohibited, whereby the topic of signaling is regarded as a grey area with unclear legal standards 79.

Challenges continue to exist in price communication vis-à-vis sales agents/retailers. The communication between the value creation stages must also be consistent. If this is not the case, the result is a communication disaster. For example, in Germany the brand Colgate was delisted by the drugstore retailer $\mathrm{dm}$ because Colgate attempted to covertly raise the price of toothpaste. The retail company positioned itself as a "defender of its customers" and refused to increase store prices.

Price communication to the outside world focuses on the customers, both the customer companies in B2B markets and/or the end customers in B2C markets. Based on the findings of Behavioural Pricing, price information can be communicated in a targeted manner in order to positively influence the subjective price perception and the individual price judgement. In the context of conveying information about the price level, the timing of the price communication must also be decided. Thus, before, during and after the actual purchase situation and decision, a variety of communication possibilities in the context of price advertising, price optics or final settlements come into question, which can positively control the price effects 5 . The perspective of the actual shopper must be taken into account, especially during the purchasing situation 80 . This has led to a real boom in customer experience research in recent years. Furthermore, a focus must be placed on the comprehensibility of price differentiation.

\section{Dependencies and interactions between price communication and other elements of the pricing process}

While one objective of this paper is to describe and acknowledge the increased importance of price communication in the pricing process in a digitized world, it is also important to point out that there are interdependencies between the individual elements of the pricing process. This also - or especially - concerns price communication, as illustrated in Fig. 3. A framework for communication is set, for example, by regulatory and legal rules, as well as by strategic orientation and positioning. At the same time, there are important interfaces in the area of customer relation management and competition.

Finally, attention should be paid to establish and measure key figures, including those for price communication, as part of a controlling process. 


\section{PRICE COMMUNICATION: QUO VADIS?}

The previous remarks have highlighted the increased complexity and the new demands on price communication and have shown that the communication of prices in the digital age must be considered in the overall strategic context of the pricing process and the communication strategy and that the dependencies of the different expectations of internal and external stakeholders must also be taken into account.

This results in partly opposing trends. For example, a stronger dynamization of prices (similar to revenue management, see Cross et al. 2011 81) will lead to individual product prices no longer being communicated at all, but rather benchmark prices or "best prices" (see Malighetti et al. 2015 82). The presentation of (available) prices in the area of luxury products is severely restricted 83. At the same time, more modularised pricing leads to the necessity of quoting several prices (depending on the service level); see the example of ancillary pricing in the airline sector, Ødegaard et al. 201684.

Dynamic pricing models partly change the way in which price communication is carried out: it is no longer an operational implementation measure, but requires strategically planned control and alignment in the overall context of pricing strategy, market research using Big Data, CRM as well as corporate communication. On the one hand, the communication of posted prices is becoming more and more disintegrating, especially in the case of dynamic or personalised pricing. On the other hand, there is an increased focus on flat rates and price simplification. Communication is then directed towards an annual fee that is independent of the individual use. In this case, an annual or monthly total amount is put in the foreground 85. Once this is paid, the customer has the full scope of services at his disposal. The annoyance of paying for individual services is eliminated (taximeter effect) 86.

In addition to the interface between corporate communications and the customer, other interfaces must also be taken into account. The involvement of all employees in the price communication process and the resulting identification of employees with the benefit arguments of prices and the associated price communication becomes more relevant when it comes to the goal of consistent price communication. Industry-specific communication elements must be used across all horizontal and vertical sales channels. Keywords such as traceability, transparency, consistent justifications especially in the case of changes, credibility, clear messages across all sales levels, benefits and usage arguments as well as networking and dependencies on all stakeholders will be the main drivers of price communication in the future and will be part of every repertoire of requirements for price communication. This means that the focus of price communication goes far beyond the current understanding.

\section{References}

1. Meffert H., Veränderungsbereitschaft ist ein Schlüsselthema. Interview: Vera Hermes, Absatzwirtschaft, 2018, (12): p. 22.

2. Krämer A., Pricing in a VUCA World - How to Optimize Prices, if the Economic, Social and Legal Framework Changes Rapidly. In: Mack, O., et al. (Eds.), Managing in a VUCA World. Springer, New York 2015, p. 115-128.

3. Krämer, A. and Kalka, R., How Digital Disruption Changes Pricing Strategies and Price Models. In: Khare, A., et al. (Eds.), Phantom ex machina: Digital disruption's role in business model transformation. Springer, New York 2016, p. 87-103. 
Kramer, A. (2020) The Strategic Value of Price Communication. Archives of Business Research, 8(5). 96-111.

4. Bennett, N. and Lemoine, G.J., What a difference a word makes: Understanding threats to performance in a VUCA world. Business Horizons, 2014. 57(3): p. 311-317.

5. Siems, F., Preisbezogene Informationen in der Kommunikation richtig vermitteln, In: Langner, T. et al. (Eds.): Handbuch Techniken der Kommunikation, Springer Gabler, Wiesbaden 2018, p. 447-462.

6. Cornelissen, J. P., Corporate communication. The International Encyclopedia of Communication. Sage, London 2008.

7. Van Riel, C.B. and Fombrun, C.J., Essentials of corporate communication: Implementing practices for effective reputation management. Routledge, London and Ney York 2007.

8. Bruhn, M., Kommunikationspolitik. Franz Vahlen, München 2019.

9. Bruhn, M., Einsatz der Mediawerbung für die Marketingkommunikation. In: Bruhn, et al. (Eds.): Handbuch Instrumente der Kommunikation, Springer Gabler, Wiesbaden 2016, p. 77-96.

10. Gedenk, K., Einsatz der Verkaufsförderung für die Marketingkommunikation. In: Bruhn, M. et al. (Eds.): Handbuch Instrumente der Kommunikation, Springer Gabler, Wiesbaden 2016, p. 97-111.

11. Brandstätter, M. et al., Kommunikation des Herstellers mit dem Handel. In: Bruhn, M./Esch, et al. (Eds): Handbuch Instrumente der Kommunikation, Springer Gabler, Wiesbaden 2016, p. 241-265.

12. Frohmann, F., Digitales Pricing. Springer Gabler, Wiesbaden 2018.

13. Simon, H. and Fassnacht, M., Preismanagement: Strategie - Analyse - Entscheidung - Umsetzung. Springer Gabler, Wiesbaden 2016.

14. Diller, H., Preispolitik. Kohlhammer, Stuttgart 2008.

15. Olbrich, R. and Battenfeld, D., Preispolitik. Springer-Gabler, Berlin 2014.

16. Schindler, R. M., Pricing strategies: a marketing approach. Sage, London 2012.

17. Baker, W. L., Marn, M. V., \& Zawada, C. C., The price advantage. John Wiley \& Sons, Hoboken 2010.

18. Smith, T. J., Pricing done right: The pricing framework proven successful by the world's most profitable companies. John Wiley \& Sons, Hoboken 2016.

19. Vocatus (2019): Preisstrategie. Retrieved from https://www.vocatus.de/de/leistungen/pricing/preisstrategie.

20. Thaler, R.H. and Sunstein, C.R., Nudge: Improving decisions about health, wealth, and happiness. Penguin, New York 2009.

21. Selinger, E., and Whyte, K., Is there a right way to nudge? The practice and ethics of choice architecture. Sociology Compass, 2011. 5(10); p. 923-935.

22. Krämer, A. and Schmutz, I., Mythos Value-Based Pricing: Der Versuch einer (wertfreien) Einordnung. Marketing Review St. Gallen, 2020. 37(2): p. 44-53.

23. Reisman, R. and Bertini, M., A novel architecture to monetize digital offerings. Journal of Revenue and Pricing Management, 2018. 17(6); p. 453-458.

24. Hinterhuber, A., Customer value-based pricing strategies: why companies resist. Journal of Business Strategy, 2008. 29(4): p. 41-50.

25. Liozu, S.M., et al., The conceptualization of value-based pricing in industrial firms. Journal of Revenue and Pricing Management, 2012. 11(1): p. 12-34.

26. Töytäri, P., et al., Organizational and institutional barriers to value-based pricing in industrial relationships. Industrial Marketing Management, 2015. 47, p. 53-64.

27. Krämer, A. and Burgartz, T., Customer Value Controlling - Combining Different Value Perspectives. Business and Management Studies, 2015. 1(2): p. 11-19.

28. Dijksterhuis, G., New product failure: Five potential sources discussed. Trends in food science \& technology, 2016. 50, p. 243-248. 
Archives of Business Research (ABR)

Vol.8, Issue 5, May-2020

29. Nielsen, Breakthrough Innovation Report 2015. European Edition. Retrieved from

http://innovation.nielsen.com/breakthrough2015EU.

30. Konya-Baumbach, E. et al., Making a first impression as a start-up: Strategies to overcome low initial trust perceptions in digital innovation adoption. International Journal of Research in Marketing, 2019. 36, p. 385-399.

31. Hoeffler, S., Measuring preferences for really new products. Journal of Marketing Research, 2003. 40, p. 406-421.

32. Castaño, R. et al., Managing Uncertainty in the Adoption of New Products: Temporal Distance and Mental Simulation. Journal of Marketing Research, 2008. 45, p. 320-336.

33. Gröppel, A., Preiswürdigkeitsimages und Preisdifferenzierungsstrategien - Der Einfluss der am Point-of-Sale empfundenen Dominanz auf die Preisbeurteilung. In: Trommsdorff, V. (Ed.): Handelsforschung, Gabler, Wiesbaden 1996, p. 297-315.

34. Meffert, H. et al., Marketing. Springer Gabler, Wiesbaden 2019.

35. Robbert, T., and Roth, S., The importance of transparency signals in à la carte pricing, Journal of Revenue and Pricing Management, 2018. 17(1): p. 32-40.

36. Warnock-Smith, D., et al., An analysis of ongoing trends in airline ancillary revenues. Journal of Air Transport Management, 2017. 64, p. 42-54.

37. Chung, J.Y. and Petrick, J. F., Price fairness of airline ancillary fees: An attributional approach. Journal of Travel Research, 2013. 52(2): p. 168-181.

38. Homburg, C., Marketingmanagement. Springer Gabler, Wiesbaden 2017.

39. Ferguson, J.L. and Ellen, P.S., Transparency in pricing and its effect on perceived price fairness. Journal of Product \& Brand Management, 2013. 22(5/6): p. 404-412.

40. Krämer A. et al., Personalisiertes und dynamisches Pricing aus Einzelhandels- und Verbrauchersicht. Marketing Review St. Gallen, 2015. 32(6): p. 28-37.

41. Jiang L. and Erdem, M., Effects of Revenue Management Pricing Strategies on Perceived Fairness. Journal of Hospitality Marketing \& Management, 2018. 27(4): p. 424-442.

42. Krämer, A., Flexibles Pricing: Risiko für starke Marken? Markenartikel, 2016. 78(12): p. 62-65.

43. Viglia, G., et al., The exploration of hotel reference prices under dynamic pricing scenarios and different forms of competition. International Journal of Hospitality Management, 2016. 52, p. 46-55.

44. Shapiro, S.L., et al., Examining consumer perceptions of demand-based ticket pricing in sport. Sport Marketing Quarterly, 2016. 25(1): p. 34-46.

45. Malasevska, I., et al., Optimal weather discounts for alpine ski passes. Journal of outdoor recreation and tourism, 2017. 20, p. 19-30.

46. Friesen, M. and Mingardo, G., Is Parking in Europe Ready for Dynamic Pricing? A Reality Check for the Private Sector. Sustainability, 2020. 12(7): p. 1-11.

47. Gode, S., Lidl setzt auf elektronische Preisschilder - Kunden müssten aber keine Nachteile befürchten sagen Experten. Businessinside online, 27.11.2019, Retrieved from https://www.businessinsider.de/lidl-digitalepreisschilder-kunden-koennten-sparen-2019-11.

48. Ziliani, C. and Bellini, S., Retail micro-marketing strategies and competition. The International Review of Retail, Distribution and Consumer Research, 2004. 14(1): p. 7-18.

49. Reisevor9, Allianz Partners stellt das Pricing um. Reisevor9.de, 26.11.19, Retrieved from https://www.reisevor9.de/inside/allianz-partners-stellt-das-pricing-um.

50. Vogel, J. and Paul, M., One firm, one product, two prices: Channel-based price differentiation and customer retention. Journal of Retailing and Consumer Services, 2015. 27, p. 126-139.

51. Cavallo, A., Are Online and Offline Prices Similar? Evidence from Large Multi-Channel Retailers. The American Economic Review, 2017. 107(1): p. 283-303. 
Kramer, A. (2020) The Strategic Value of Price Communication. Archives of Business Research, 8(5). 96-111.

52. Keldenich, K., Besonderheiten der Preiskommunikation im mehrstufigen Vertrieb am Beispiel der Sanitärbranche. In: Kalka, R. and Krämer, A. (Eds): Preiskommunikation - Strategische Herausforderungen und innovative Anwendungsfelder, Springer Gabler, Wiesbaden 2020, p. 237-253.

53. Krämer, A. and Bongaerts, R., ÖPNV-Nutzungspotenziale und eTarife/Tickets. Der Nahverkehr, 2018. 36(9): p. 6369.

54. Lewis, M., Research note: A dynamic programming approach to customer relationship pricing. Management Science, 2005. 51(6): p. 986-994.

55. Ryals, L., Making customer relationship management work: the measurement and profitable management of customer relationships. Journal of Marketing, 2005. 69(4): p. 252-261.

56. Siems, F, and Röhr, E., Preis im Relationship Marketing - Ansätze und Potenziale. Marketing Review St. Gallen, 2017. 34(6): p. 34-39.

57. Kopetzky, M., Preispsychologie: in vier Schritten zur optimierten Preisgestaltung. Springer-Verlag. Wiesbaden 2015.

58. Koschate-Fischer N. and Wüllner, K., New developments in behavioral pricing research. Journal of Business Economics, 2017. 87(6): p. 809-875.

59. Vöster, J., Irrationaler Kunde - Effekte verstehen und nutzen. Marketing Review St. Gallen, 2015, 32(2): p. 46-52.

60. Krämer, A., Bounded Irrationality - Chancen und Grenzen beim verhaltensbasierten Pricing. Marketing Review St. Gallen, 2018. 35(2): p. 102-110.

61. Larson, R.B., Psychological Pricing Principles for Organizations with Market Power. Journal of Applied Business and Economics, 2016. 16(1): p. 11-25.

62. Krämer, A., Using Experimental Survey Designs to Support Pricing Decisions. Business Management Horizons, 2016. 4(1): p. 22-38.

63. Schade, A.K., Berliner Versicherungs-Startup Friday bekommt 75 Millionen. Gruenderszene.de v. 7.3.2019, Retrieved from https://www.gruenderszene.de/automotive-mobility/friday-autoversicherung-75-millionen.

64. Hinterhuber, A. and Liozu, S.M., Is innovation in pricing your next source of competitive advantage? BusinessHorizons, 2014. 57, p. 413-423.

65. Jittrapirom, P., et al., Mobility as a service: A critical review of definitions, assessments of schemes, and key challenges. Urban Planning, 2017. 2(2): p. 13-25.

66. Perktold, F., and von Raczeck, M., PSS Design in Practice - How a Choice Experiment Can Help Configuring a New Subscription Offer. The Case of Care by Volvo's Used Car Subscription Offer. Göteborg 2019.

67. Spann, M., et al., Beyond Posted Prices: The Past, Present, and Future of Participative Pricing Mechanisms. Customer Needs and Solutions, 2018. 5(1-2): p. 121-136.

68. Koeppel, S., Fallstudie: Preiskommunikation bei beckers bester. In: Kalka, R. and Krämer, A. (Eds.): Preiskommunikation - Strategische Herausforderungen und innovative Anwendungsfelder, Springer Gabler Verlag, Wiesbaden 2020, p. 339-350.

69. Anderl, E. et al. Mapping the customer journey: Lessons learned from graph-based online attribution modeling. International Journal of Research in Marketing, 2016. 33(3): p. 457-474.

70. Grund, M., Interaktionsbeziehungen im Dienstleistungsmarketing: Zusammenhänge zwischen Zufriedenheit und Bindung von Kunden und Mitarbeitern. Springer-Verlag, Wiesbaden 2013.

71. Lauszus, D. and Bastgen, J., Fallstudie: Interne Preiskommunikation - Einbindung des Vertriebs als kritischer Erfolgsfaktor. In: Kalka, R. and Krämer, A. (Eds.): Preiskommunikation - Strategische Herausforderungen und innovative Anwendungsfelder, Springer Gabler Verlag, Wiesbaden 2020, p. 221-235.

72. Krämer, A. and Beger, F., Die Rolle des Vertriebsteams bei der Umsetzung von Konditionensystemen. Sales Management Review, 2017. 26(6): p. 78-85. 
73. Krämer A. and Böhrs S., Erklärvideos als effektives und effizientes Marketing-Instrument. Marketing Review St. Gallen, 2017. 34(12): p. 54-61.

74. Fallon, F., Warum Teslas wichtigster Geldgeber die Ablösung von Elon Musk anregt. Manager Magazin 22.8.2019, Retrieved from https://www.manager-magazin.de/premium/tesla-james-anderson-von-baillie-gifford-ueberdie-schwaechen-von-elon-musk-a-d9d40c45-de5b-497d-9081-49cac593f930.

75. Hofbauer, G. and Knör, S., Professionelles Preismanagement: Die Komponenten langfristig wirksamer Preisgestaltung. Publicis Publishing, Erlangen 2015.

76. Wilger, G. and Krämer, A. Signaling gegenüber Wettbewerbern - Erkennen und Verhindern von Preiswettbewerb und „Preiskrieg“. In: Kalka, R. and Krämer, A. (Eds.): Preiskommunikation - Strategische Herausforderungen und innovative Anwendungsfelder, Springer Gabler Verlag, Wiesbaden 2020, p.129-149.

77. Krämer, A., et al., A Small Step from Price Competition to Price War - Understanding Causes, Effects and Possible Countermeasures. International Business Research, 2016. 9(3): p. 1-13.

78. Bungert, M., The Termination of Price Wars - A Signaling Approach. DUV, Wiesbaden 2016.

79. Jandl, F., Kommunikationsfallen im Graubereich des Kartellrechts. Unternehmensjurist, 2016. 4, p. 50-52.

80. Dräger, P., Instore-Preiskommunikation aus Shoppermarketing-Perspektive. In: Kalka, R. and Krämer, A. (Eds.): Preiskommunikation - Strategische Herausforderungen und innovative Anwendungsfelder, Springer Gabler, Wiesbaden 2020, p. 307-323.

81. Cross, R.G., et al., Milestones in the application of analytical pricing and revenue management. Journal of Revenue and Pricing Management, 2011, 10(1): p. 8-18.

82. Malighetti, P. et al., EasyJet pricing strategy: determinants and developments. Transportmetrica A: Transport Science, 2011. 11(8): p. 686-701.

83. Schmutz, I. et al., Preiskommunikation im Marktsegment Luxus - eine Frage der Konditionierung, nicht der Konditionen. In: Kalka, R. and Krämer, A. (Eds.): Preiskommunikation - Strategische Herausforderungen und innovative Anwendungsfelder, Springer Gabler, Wiesbaden 2020, p. 369-383.

84. Ødegaard, F. and Wilson, J.G., Dynamic pricing of primary products and ancillary services. European Journal of Operational Research, 2016. 251(2): p. 586-599.

85. Herweg, F., and Mierendorff, K., Uncertain demand, consumer loss aversion, and flat-rate tariffs. Journal of the European Economic Association, 2013. 11(2): p. 399-432.

86. Lambrecht, A., and Skiera, B., Paying too much and being happy about it: Existence, causes, and consequences of tariff-choice biases. Journal of marketing Research, 2006. 43(2): p. 212-223. 